\title{
The Qinling orogen and intracontinental orogen mechanisms
}

The Qinling orogen is a composite continental orogen with a complex evolutionary history. During the Early and Middle Proterozoic: it was a continental rift; in the late Proterozoic, it began to be part of a plate tectonic regime; from the Palaeozoic to Early Mesozoic, it was involved in subduction-collision between three plates; and in the Mesozoic and Cenozoic, it was affected by intracontinental postorogenic tectonism. The Qinling orogen has a flyover-shaped, 3-D lithospheric architecture.

\section{Introduction}

The Qinling orogen extends from cast to west in the middle of the China continent. Linking the Dabic Mountains in the east and the Qilian and Kunlun mountains in the west, it is in a geotectonically important position. It is now believed to be a unique composite continental orogen with a complicated composition and structure. It hats undergone evolution under different tectonic regimes during its long developmental history. constrained by different tectono-dynamic systems of the palateo-Pacitic. Tethys, Laturasia and Gondwanaland.

\section{Main tectonic units and evolutionary stages}

The main tectonic units of the Qinling orogenic belt are shown in Figure 1. Primarily, the belt is composed of three distinct tectonolithostratigraphic units, which possess different crustal compositions and textures, and which evolved under different tectonic regimes in three stages. The lower unit represents two kinds of orogenic basement. One is a Late Archaean-Farly Proterozoic metamorphic crystalline complex, now dispersed in the orogenic belt making it very hard to reconstruct the early history. The other is a widely outcropping Middle Proterozoic sedimentary-volcanic low-grade metamorphosed succession. which is actually a sort of transitional havement formed in extensional tectonic settings. It is evident that intense rifting occurred at $800-1000 \mathrm{Ma}$ and the succession was produced in a mosaic rift valley and small ocean basin environment (Zhang, 1988). The middle unit is a Late Proterozoic Middle Triassic succession, consisting of depositional sequences developed at both active and passive continental margins; subduction-related opholites, and collisional granites. All these demonstrate a plate tectonic regime at this stage (Li et al., 1978; Mattatter et al., 1985; Hsu et al.. 1987; Zhang. 1988: Xu et al., 1986; Ren, 1991). In addition, widespread basement uplift also implies subcrustal underplating and vertical accretion (Platt, 1993; Michard, 1993). The upper unit is made up of both intrusive granites and sediments deposited in forcland-, hinterland-, and postorogenic-rifted basins. The Meso-Cenozoic intracontinental rift faulting, tectono-magmatism and tectonic deformation indicate an intracontinental orogenesis following the main period of strong orogenic movement. The Qinling orogen was actually a branch of the northern flank of palaeo-Tethys from the Late Proterozoic to the
Palacozoic. Two limited oceans originated during this time and the Qinling microplate was then separated from the north China plate and the Yangtze plate. Subduction of oceanic crust took place in the Early and Middle Palaeozoic, accompanied by coeval vertical underplating and accretion. Continent-continent collision occurred from the Carboniferous to the Middle Triassic in an oblique and diachronous fashion, creating two major suture zones, that is, the northern Shangdan suture zone and the southern Mianlue suture zone. Intense Mesozoic-Cenozoic intracontinent orogeny brought about rapid uplift and eventually formed the present-day Qinling.

\section{Processes in, and the characteristics of, the main Qinling orogeny}

The main phase of the Qinling orogeny was in the I atte Proterozoic Early Mesozoic. The processes operating and characteristics of the orogeny can be summarised as follows.

\section{Breakup of the Late Proterozoic Qinling lithosphere and change in the tectonic regime}

A preliminarily united Yangtze Block formed as a result of complex integration of segments of crystalline basement during the Jinningian $(1000)-800 \mathrm{Ma}$ ), but the Qinling, (the northern margin of the Yangtze Block at that time) was still suffering extention and breakup. Rifting-related volcanism was intense along the Shangdan fault and Shangxian fault from the Late Proterozoic to the Early Palaroroic. A Qinling proto-ocean was initiated by continuous rifting in the pre-Sinian period and caused the north China plate to become separated from the Yangtze plate.

The evidence for this important transition from a continental rift regime in the Middle Proterozoic to a plate tectonic regime in the I ate Proterozoic includes the following:

- The Yangtze-type Sinian is developed only to the south of the Shangdan fault and has never been found to the north.

- Different kinds of ophiolitic and volcanic rocks (983 Ma: 357-4(12 Ma) are preserved within or beside the Shangdan zone (Zhang et al.. 1994: Li et al.. 1989).

- There are also suhductional and collisional granites (382-440) Ma: 323 210 Ma) (Zhang et al., 1992; Zhang et al.. 1994).

- The northern margin of the Yangtze plate shows geological fcatures of a passive continental margin, while the southem margin of the north China plate has the character of an active margin.

\section{Subduction-collision from the Palaeozoic to the Early Mesozoic}

Following the establishment of the north China plate and Yangtze plate in the Late Proterozoic, the continuing evolution of the Qinling was not simply a response to the interaction and lateral movement of these two plates. Further extension of palaeo-Tethys led to the formation of a rifted zone along the present-day Mianlue lault ( $\mathrm{SF}_{2}$, Figure 1) during the interval from the Devonian to the Carboniferous. This rift was a new branch of the northern flank of palaeo Tethys, scparating the Qinling plate from the Yangtze plate. and 


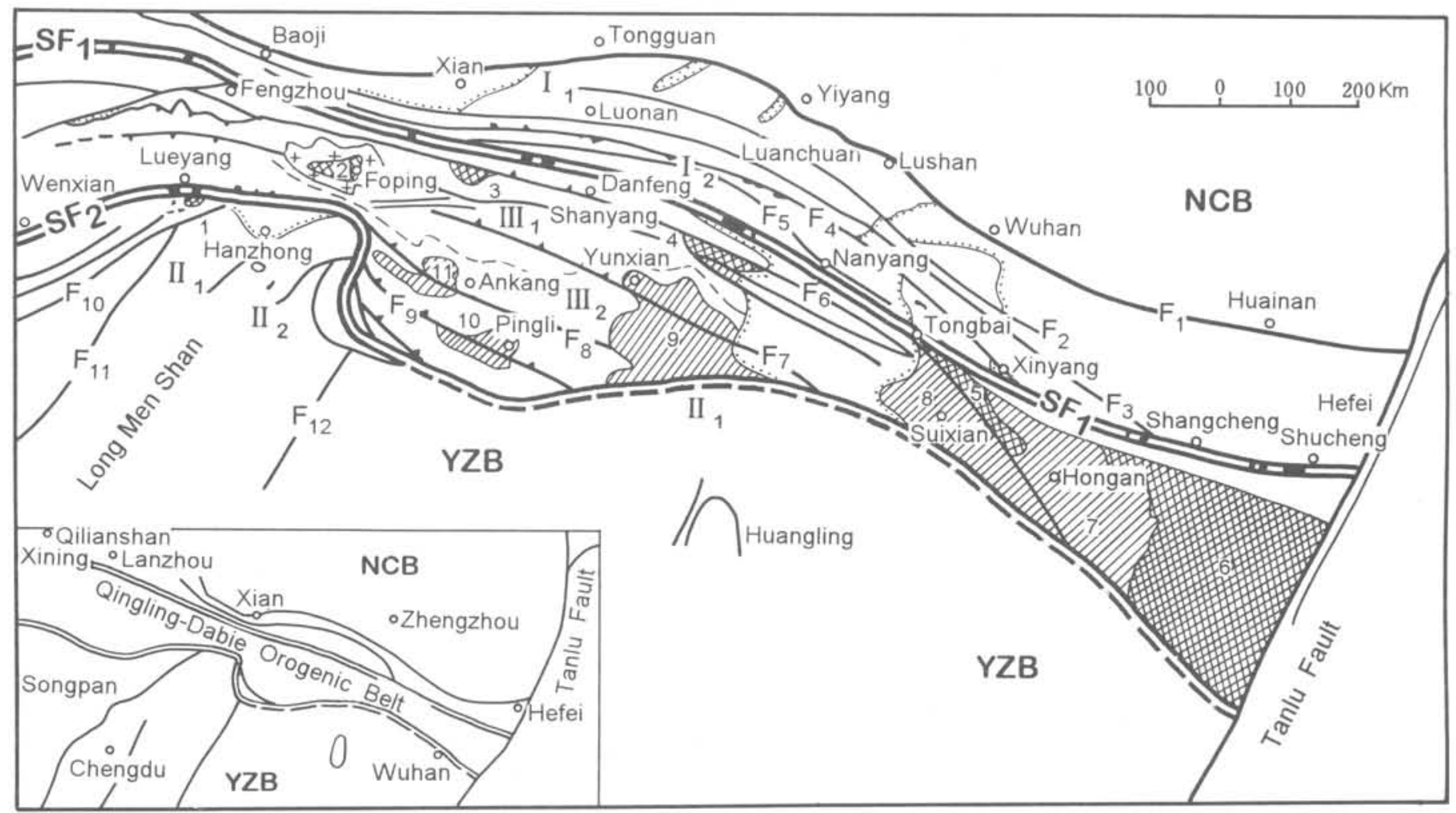

Figure 1 Major tectonic units of the Qinling Orogenic Belt.

I South margin of North China Block

$\mathrm{I}_{1} \quad$ hinderland thrust-fold zone

$\mathrm{I}_{2}$ thick-skinned imbricated thrust zone

II Northern margin of Yangtze Block

$\mathrm{II}_{1}$ foreland thrust-fold zone

$\mathrm{II}_{2}$ large-scale frontal thrust zone on the south margin of Bashan-Dabie Mountains

III Qinling microplate

$\mathrm{III}_{1}$ Late Palaeozoic rifted zone in the northern part of south Qinling

$\mathrm{III}_{2}$ Late Palaeozoic uplifted zone in the southern part of south Qinling

$\mathrm{SF}_{1}$ Shangdan suture zone

$\mathrm{SF}_{2}$ Mianlue suture zone

Major faults:

$\mathrm{F}_{1} \quad$ Northern boundary fault of Qinling

$\mathrm{F}_{2} \quad$ Shimen-Machaoying thrust fault

$\mathrm{F}_{3}$ Luonan-Luanchuan thrust fault

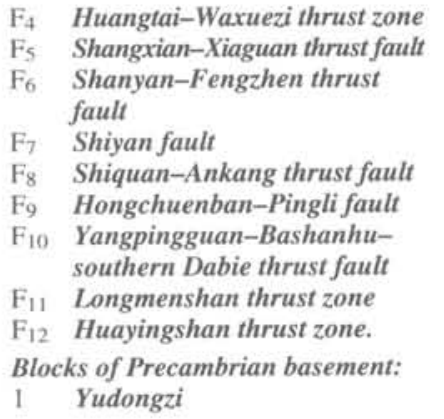

gradually becoming another suture zone (the southern suture zone, $\mathrm{SF}_{2}$ ) with the features of subduction and collision. The western segment of this suture zone is marked by a typical ophiolitic melange but the eastern segment was buried due to large-scale southward thrusting along the Bashan fault and the southern edge of the Dabie Mountains (Figure 1) in the Mesozoic. Nevertheless, some remnants of the Mianlue suture zone can still be traced in Zhenba, southern Suizhou, and the southern Dabie Mountains. The Mianlue suture zone is strongly modified and less exposed, but it is apparently connected with the Kunlun orogen to the west by the Huashixia suture zone in Qinghai. It is clear that the Qinling, including most of the Dabie Mountains, became an independent lithospheric plate in the Devonian and was located between the northern and southern suture zones. However, it has an Early-Middle Proterozoic basement similar to that of the Yangtze plate and a passive continental margin sedimentary sequence (Sinian-Early Palaeozoic) which belongs to the north margin of the plate. So, the Qinling was part of the Yangtze plate during the Early Palaeozoic, and began its own development in the Devonian.

The evidence shows that the Qinling was built up by subduction and collision between three plates along two suture zones and that the orogeny was further complicated by the presence, between the plates, of a number of continental fragments. The Qinling orogeny is too complicated to be explained by simple Caledonian or Indosinian

subduction and collision processes. Rather, it developed along the lines of the following:

1 Lithospheric breakup led to the initiation of the Qinling protoocean and the establishment of both the north China plate and Yangtze plate in the early Late Proterozoic (1000-700 Ma).

2 The Qinling proto-ocean continued to develop and the north China plate, Yangtze plate, and, from the Sinian to Cambrian (700-500 Ma), numerous rifted continental blocks moved laterally.

3 Subduction of the Yangtze plate beneath the north China plate took place, resulting in Early Palaeozoic (Caledonian) magmatism, and two distinct continental margins, active and passive, were involved in the Ordovician-Silurian (500-400 Ma).

4 The southern rifted zone was initiated in the Devonian, and the Qinling plate broke away from the Yangtze plate. Convergence continued in the Shangdan suture zone.

5 The Qinling proto-ocean at the Shangdan zone was diminishing and became isolated remnants because of irregularity of the continental margin during the initial collision in the Late Devonian and Carboniferous (370-290 Ma).

6 The residual Qinling proto-ocean was filled up and became a marsh indicating eventual diminishment of the Qinling protoocean in the Carboniferous and Permian. The final intense continent-continent oblique collision occurred in the Middle Triassic 
between the north China plate and Qinling plate, and was followed by the closure of the Mianlue proto-ocean and collision between the Qinling plate and Yangtze plate. Intracontinental tectonism has predominated in the late development of the Qinling since then (290-200Ma).

\section{Lateral and vertical accretion}

The Qinling orogeny was not only initiated by lateral motion, with consequent breakup, collision and integration of three plates and microcontinental fragments, but was also greatly influenced by the coeval vertical uplift of crystalline basements and the accompanying magmatism and metamorphisml. The Foping dome may serve as a good example. It is ellipsoid-shaped and has an Early Proterozoic complex core which is in fault (shear zone) contact with the overlying Sinian-Devonian sequences. The Foping dome represents not only a centre of magmatic complex, implying a deep-seated hot magmatic source, but also a thermal centre for metamorphism. This is well demonstrated by a decrease in metamorphic grade from the centre outwards. The dome was not only formed by lateral plate motion and crustal extension but also to a great extent controlled by mantle upwelling. This inference is supported by the occurrence of an alkaline mafic and ultramafic crypto-volcanic complex (431 Ma) with inclusions (900-700 Ma) of deep origin (Huang, 1993) in the south part of the Qinling. Vertical accretion and growth of the Qinling lithosphere could be a direct response to mantle fluid movement and magmatic diapiring. Clearly, the unique characteristics of Qinling orogen are a consequence of combined lateral and vertical tectonic activity.

\section{Postorogenic intracontinental tectonism and mechanisms}

After the Middle Triassic collision, the Qinling orogen entered a postorogenic phase when the intracontinental tectonism was still active and intense.

\section{Intracontinental features}

Block collapse, strike-slip faulting and thrusting were dominant in the Early Mesozoic. Block faulting and subsidence were induced by rapid uplift due to continuous subduction within the continental lithosphere, and most basins took the form of half grabens filled with Upper Triassic-Lower Cretaceous red beds. Oblique subduction led to pronounced strike-slip faulting and the formation of some smallscale pull-apart basins along the Shangdan suture zone. In general, the Qinling was in a compressive tectonic setting and was marked by large-scale multi-layered thrusting and granitic magmatism. In contrast, the southern margin of the north China plate was subducted southward in the zone $\left(\mathrm{F}_{2}\right)$ to the north of the Shangdan fault, causing northward thrusting. As a result, the whole Qinling structural profile is asymmetrically fan-shaped from north to south.

The Late Mesozoic development of the Qinling was characterized by intense crustal extension, rapid uplift, and large-scale granitic magmatism and mineralisation, suggesting an important thermo-tectonic event. The Qinling has been elevated over $10 \mathrm{~km}$ since the Late Cretaceous. Large-scale and widespread sialic magmatic intrusion and mineralisation occurred around $100 \mathrm{Ma}$, while sedimentary layers in the Late Triassic-Edrly Cretaceous faultbounded basins were deformed and slightly metamorphosed

Two north-south-trending belts of gravity gradient have appeared in the China continent since the Mesozoic, marking a series of north-south fault-bounded basins in west Henan and at the boundary between Shaanxi and Gansu provinces, respectively. These two belts divide the Qinling into three segments, which are, from west to east, the west Qinling, the east Qinling and the Dabie Mountains The segments have been elevated at different rates and eroded to differ- ent depths, so they are now often treated as three new distinct tectonic elements. This implies a tendency of breakup of the Qinling-Dabie orogen.

\section{The lithospheric architecture}

\section{Deep-seated structures}

Geophysical studies (Yuan, 1991), have shown that the Qinling lithosphere is markedly inhomogeneous. It is vertically layered and laterally segmented. The upper surface of the asthenosphere is at a depth of some $110 \mathrm{~km}$ in the southern Qinling, but deepens to 250 $\mathrm{km}$ in the area to the north of the Shangdan suture zone and along the Bashan zone. This difference in depth is up to about $150 \mathrm{~km}$ and must be of great dynamic significance. The crustal thickness also varies. East of longitude $108^{\circ} \mathrm{E}$, the crust is about $32 \mathrm{~km}$ thick and the Moho is flat, indicating the absence of a mountain root; west of it, the crustal thickness reaches $56 \mathrm{~km}$. There is a strong, flat seismic reflection in the middle crust, which is now proved to be a lowvelocity, highly conductive layer. The Qinling is an area with high heat flow, which may be related to partial melting in the middle crust. This inference comes from study of granites which originated at depths of $15-20 \mathrm{~km}$. Evidently, the middle crust as well as the upper part of the lower crust in the Qinling represents a rheological soft stratification and is also an intracrustal dynamic layer. CT studies of the Qinling region demonstrate that the lower lithosphere, below the depth of $20-40 \mathrm{~km}$, shows spaced north-south-trending zones with different tectono-geophysical states, while the upper. above $20 \mathrm{~km}$, is dominated by east-west-trending structural lineaments. A flat deformation zone lies between the lower and upper lithosphere. The 3-D geometrical pattern of the Qinling region is much like a flyover and is one of the remarkable features of the Qinling structure

\section{Upper crustal structures of the present Qinling}

The Qinling is connected in the east with the Dabie Mountains. Different tectonic levels of the crust have been exposed by denudation from east to west. The orogenic root zone crops out in the Dabie Mountains; both deep and middle levels are exposed in the east Qinling; while the west Qinling is dominated by sedimentary cover with less outcrop of crystalline basement. The denudation of ultrapressure root zone on the Dabie Mountains implies much stronger shrinking and uplifting of the crust than in the Qinling. The Qinling northsouth-trending profile is fan-shaped due to northward subduction and final collision. The southern part is marked by southward thrusts and the northern part shows opposite vergence. The northern part of the Qinling is the orogenic core and is characterised by thick-skinned southward imbricated thrusts (Figure 1). In the southern Qinling. structural vergence represents lateral variations along the strike, that is, the vergence changes on the east and west sides of the Foping dome. The thrusting is southward on the east and northward on the west, and a transfer zone exists in between. The present complex structural pattern of the Qinling has come about by the superposition of vertical accretion at depth and large-scale thrusting in the upper crust.

\section{Dynamic analysis}

Any analysis of the mechanism of Mesozoic-Cenozoic intracontinental orogeny and 3-D geometrical pattern of the Qinling should take into account the following.

- The present 3-D framework of the Qinling was established during the main orogeny, but some early structures can still be traced and the Mesozoic-Cenozoic reformation is much more manifest. The deep-seated structures reflect the state of recent tectonic readjustment.

- The Mesozoic-Cenozoic intracontinental orogeny was mainly controlled by the Asian continent, Pacific and Indian plates. The east part of the Qinling was much more influenced by the Pacific plate, resulting in dynamic and kinetic adjustment of the Qinling lithosphere. The deep-seated rheological adjust- 
ment led to the north-south-trending tectonophysical and textural zonation in the Qinling lithospheric mantle. In contrast, ancient east-west-trending structures may be preserved because they have been hardened during the postorogenic period and have not yet been fully modified. The middle and lower crust is in a transitional position, where the orogenic root was erased due to the rheological flattening. The flyovershaped 3-D framework of the Qinling lithosphere was thus created. The middle and lower crust, as a soft rheological stratification in the lithosphere, can not only absorb strain and energy of mantle tectonic adjustment, but also controls material exchange and structural deformation of the upper crust (Ranalli and Murphy, 1987; Quinlan, 1993). Therefore, deep-seated mantle adjustment and the middle-lower crustal rheological state were important dynamic mechanism for the intense intracontinental Qinling orogeny in the Mesozoic and Cenozoic.

- Deep geophysical studies reveal that the asthenosphere, under the main body of the Qinling, strongly upwelled to depths of $60-80 \mathrm{~km}$ and the lithosphere sharply thinned accordingly. There are two mechanisms for this upwelling. One is the large-scale lateral migration of material in the rheological layer; the other is that some parts of the lithosphere melted away by the rising asthenosphere. Intense extension occurred in the Mesozoic, especially in the Late Cretaceous, resulting in rapid crustal uplift and large-scale magmatic activity. Lithospheric mantle delamination (Kay and Kay, 1993; Sacks, 1993) and asthenospheric upwelling are believed to be the main dynamic causes of the Mesozoic-Cenozoic intracontinental orogeny of the Qinling.

\section{Acknowledgement}

This project is supported by the National Natural Science Foundation of China (NSFC) and the Ministry of Geology and Mineral Resources of China, Grant 49290100.

\section{References}

Huang, Y, 1993, Mineralogical characteristics of phlogopite-amphibolepyroxenite mantle xenoliths included in the alkali mafic-ultramafic subvolcanic complex from Langao county, China: Acta Petrologica Sinica, v. 4 , pp. $367-378$.

Hsu, K J, Wang, Q, Li, Z, and Sun, S, 1987. Tectonic evolution of Qinling Mountains, China: Eclogae Geologicae Helvetiae v. 83, pp. 735-752.

Kay, R W, and Mahlbury-Kay, S, 1993, Delamination and delamination magmatism: Tectonophysics, v. 219, pp. 177-189.

Li, C, Liu, Y, Zhu, B, Feng, Y, and Wu, H, 1978, Tectonic evolution of the Qinling and Qilian Mountains: Proceedings of International Geological Symposium, pp. 77-183.

Li, S, Hart, S R, Zhang, S, Liu, D, Zhang, G, and Guo, A, 1989, Timing of collision between the North and South China blocks-the Sm-Nd isotopic age evidence: China Science ser. B, v. 32, pp. 1291-1400.

Mattauer, M, Matte, P, Malavieille, J, Tappornier, P, Maluski, H, Xu, Z, Lu, Y, and Tang, Y, 1985, Tectonics of the Qinling belt: buildup and evolution of eastern Asia: Nature, v. 317, pp. 496-500.

Michard, A, 1993, Compression versus extention in the exhumation of the Dora-Maira coesite-bearing unit, Western Alps, Italy: Tectonophysics, v. 221, pp. 173-193.
Platt, J P, 1993, Exhumation of high-pressure rocks: a review of concepts and process: Terra Nova, v. 5, pp. 119-133.

Ranalli, G, and Murphy, D, 1987, Rheological stratification of the lithosphere: Tectonophysics, v. 132, pp. 261-295.

Ren, J, 1991, On the Qinling orogenic belt-integration of the Sino-Korean and Yangtz blocks, in Ye, L, Qian, X, and Zhang, G, eds., A selection of papers presented at the conference on the Qinling Orogenic Belt: Northwest University Press, Xi'an, pp. 99-110.

Quinlan, G, 1993, Tectonic model for crustal seismic reflectivity pattern in compressional orogens: Geology, v. 21, pp. 663-666.

Scaks, P.G, 1990, Delamination in collisional orogens: Geology, v. 18, pp. 999-1002.

Xu, Z, Tang, Y, and Lu, Y, 1986, Deformational features and tectonic evolution of the East Qinling: Acta Geologica Sinica, v. 60, pp. 237-247.

Yuan, X, 1991, Deep structure and structural evolution of the Qinling orogenic zone, in Ye, L, Qian, X, and Zhang, G, eds., A selection of papers presented at the conference on the Qinling Orogenic Belt, Northwest University Press, Xi'an, pp. 174-184.

Zhang, B, Luo, T, Gao, S, Ouyang, J, Gao, C, and Li, Z, 1992, Petro-geochemical features and geological significance of the Qinling and Bashan regions, in Zhang, B, ed., Contributions to regional geochemistry of Qinling and Daba Mountains: China University of Geosciences Press, Wuhan, pp. 1-31.

Zhang, G, 1988, Formation and evolution of the Qinling Orogenic Belt: Northwest University Press, Xi'an, 192pp. .

Zhang, G, Yu, Z, Sun, Y, Chen, S, Li, T, Xue, F, and Zhang, C, 1989. The major suture zone of the Qinling orogenic belt: Journal of Southeast Asian Earth Sciences, v. 3, pp. 63-76.

Zhang, Z, Liu, D, and Fu, G, 1994. Isotopic chronological studies of the North Qinling metamorphic succession: the Qinling, Kuanping, and Taowan Groups: Geological Publishing House, Beijing, 191pp.

Professor Guowei Zhang is Head of the Institute of Orogenic Geology, Northwest University. He is mainly engaged in studies of Precambrian geology, structural geology and tectonics. As a leader, he is now in charge of the important project: Structure, Evolution and Mineralization of the Qinling Orogen, supported by the National Natural Science Foundation of China (NSFC).

Professor Liwen Xiang is a senior research fellow of the Institute of Geology, Chinese Academy of Geological Sciences. His current research interests include Palaeozoic stratigraphy, palaeontology and Qinling regional geology. He is the Vice-President of the Palaeontological Society of China and a member of the Subcommission on Cambrian Stratigraphy (ICS).
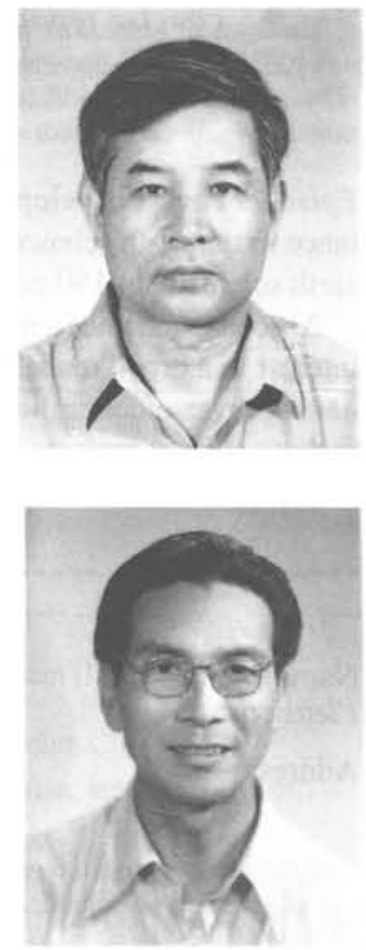


\section{EXPANDYOUR HORIZONS}

Answer your global earth-science information needs with

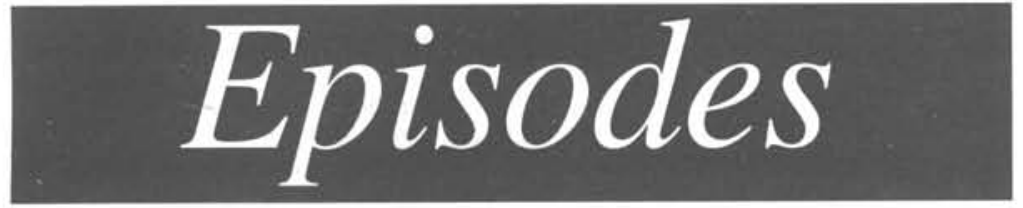

the international geoscience news magazine published quarterly by the International Union of Geological Sciences

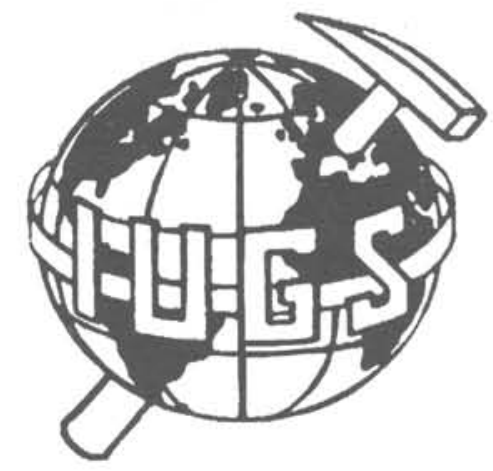

Offering you

- authoritative articles that reflect worldwide research advances and evolving trends in geoscience

- a forum for information exchange within the global earth-science community

- book reviews by experts in your field

- a comprehensive calendar of future international geoscience events and training opportunities

- concise reports about results of international meetings, conferences and symposia

Episodes covers developments of regional and global importance in the earth sciences and is distributed worldwide to earth scientists in 150 countries.

Articles contributed to Episodes are innovative and of interest to a broad readership of professional scientists having diverse cultural and linguistic backgrounds. Articles include current reviews, new results from research projects of more than local significance, and discussions of the infrastructure of science-techniques, research programmes, organisations, science policy, or technical assistance.

A specimen copy may be obtained from the Editor, Episodes, British Geological Survey, Keyworth, Nottingham, England NG12 5GG
Name

Please print

Address

To start your subscription, complete this form and send it to:

Episodes, Regency Fulfilment Services

120-126 Lavender Ave, Mitcham, Surrey CR4 3HP UK

\& $+44(0) 1816461031$

Fax $+44(0) 1816484873$
Episodes-your window to the world! Subscribe today

Payment may be made by:

- Cheques (US \$ or $£$ sterling) made payable to Episodes

- $\square$ Visa or $\square$ Mastercard

Please quote account number, expiry date and signature

Account \#

Expiry date

Signature

Annual subscription rates: $£ 16$ sterling or US \$24 